\title{
Development of Industry Linking Cluster in Vietnam
}

\author{
Le Thi Thuong \\ Hung Yen University of Technology and Education, Khoai Chau, Vietnam \\ Email: lethuongkt.utehy@gmail.com
}

How to cite this paper: Thuong, L. T. (2020). Development of Industry Linking Cluster in Vietnam. American Journal of Industrial and Business Management, 10, 1368-1373.

https://doi.org/10.4236/ajibm.2020.108091

Received: July 17, 2020

Accepted: August 15, 2020

Published: August 18, 2020

Copyright $\odot 2020$ by author(s) and Scientific Research Publishing Inc. This work is licensed under the Creative Commons Attribution-NonCommercial International License (CC BY-NC 4.0). http://creativecommons.org/licenses/by-nc/4.0/

\begin{abstract}
Vietnam has quickly become a developed economy, proactively integrating into the global economy. Industry linking clusters play an important role in the nation's socio-economic development. The industry linking clusters in Vietnam have been relatively developed. However, they have still loose and inconsistent. The present study has given some solutions and a number of lessons to develop industry linking clusters in Vietnam by using related secondary data collection methods, synthesis, analysis and statistics.
\end{abstract}

\section{Keywords}

Industry Linking Clusters, Industry Linking Cluster Development, Cluster

\section{Introduction}

Industry linking cluster has been presented and developed by Alfred Mashall in many economic works. Since 1993, the United Nations Industrial Development Organization (UNIDO) has initiated a program of industrial park strategy development around the world and defines industry linking cluster with focusing on geographic of enterprises in the same industry to facilitate mutual support (Marshall, 1920). Rosenfeld (1997) focused on the importance of social communication and business linkages in determining the nature of industry linking cluster. They have also expanded its relationship with companies that provided ancillary services, including suppliers, consultants, education, training, financial institutions, professional associations and government agencies. The industry linking cluster has been affirming that the cluster brings many benefits to enterprises, local economy in particular and economy in general (Kuchiki \& Tsuji, 2008; Porter, 1990; Sonobe \& Otsuka, 2006). The industry linking cluster is a form of organization for concentrating of enterprises, forming production areas 
by industry, by product. The association and cooperation among businesses in the industry linking cluster are important requirement to have success of the industry linking cluster. The enterprises will participate in the production value chain from the supply of raw materials to the stage of delivering products to consumers. In each industry linking cluster, there are many enterprises that produce products and raw materials; supply raw materials, machinery, tools, and spare parts; consume and export products. In industry linking cluster, there may also be organizations that provide legal services, training, business support, verification, certification of origin, goods, and logistics, ... With such a combination of businesses and organizations, industry linking cluster play a large role in organizing relationship among economic entities.

Vietnam's economy is deeply integrated into the global economy. However, the growth model and process of industrialization have revealed some problems such as: width growth based on cheap labor, capital intensive, low labor productivity, mainly processing, assembling... with low added value. Vietnam needs to improve its competitiveness, build an industrial strategy, focus on developing industry clusters to achieve the set goals. The reality of industry linking cluster in Vietnam is mainly formed and developed naturally with low sustainability and dynamism, loose relationships, and lack of links with enterprises inside and outside the cluster. Vietnam has not had an effective strategy and policy to form and develop the industry linking cluster. In order to develop the national economy, the success of East Asia, especially countries such as China, South Korea and Japan in using policy for industry linking cluster development as an important tool of the government is good practical experience for Vietnam to refer and learn. The present study has given some solutions and a number of lessons to develop industry linking clusters in Vietnam by using related secondary data collection methods, synthesis, analysis and statistics.

\section{Overview of Developing Industry Linking Clusters in Many Countries}

From 1950s to present, the industry linking clusters have been developed in different areas of China. Firstly, the industry linking clusters were mainly planned in the eastern part of the country and then moved to the Southeast. The largest aggregation of clusters is concentrated in the provinces of Jiangsu, Shanghai, Zhejiang, Fujian and Guangdong with products from traditional industries such as textiles, leather and furniture. and metal products. These industry linking clusters have the following characteristics: Firstly, the industry linking clusters operate in low technology industries and high labor intensity; Secondly, the industry linking clusters show specialization in the sectors of the region; Thirdly, the development of industry linking clusters should not be put in the development of urban areas; Fourthly, the industry linking clusters does not follow a rule of technological or financial development (Hạnh, 2014). In China, there are mainly two forms of the industry linking clusters: "from top to bottom" and 
"from bottom to top". The development orientation of industry linking clusters may come from organizations and enterprises in the industry linking clusters that have been formed to promote the competitiveness and performance of cluster (from the bottom up). The other case from Government has been mainly funded through a national or regional program on developing industry linking clusters (from top to bottom). Regarding to the quality of products in the planning, the government will create conditions to help increase the ability to attract foreign direct investment capital, create employment opportunities, technology transfer and improve professional skills as well, ... However, one limitation of these types of industry linking clusters is the lack of uniformity with the remaining industries in the region. In contrast, the industry linking clusters of "from the bottom up" has been formed before, with the intervention of local and central governments in order to support and assist businesses in research and development activities, market access and human resource training. These industry linking clusters develop more effectively and aggressively than others. These industry linking clusters are developed mainly based on the strength and ability to specialize in manufacturing in the local history, which creates a solid and lasting development foundation.

From 1960s, the policy of developing industry linking clusters in South Korea has applied to grow economy with the fastest growth in modern world history. The country's GDP jumped from US\$ 100 in 1963 to US\$ 10,000 in 1995 and US\$25,000 in 2007. Table 1 presents the policies for developing industry linking clusters in South Korea from 1960s to present. Policymakers have found that developing industry linking clusters will help enterprises in the cluster to easily access inputs (eg. suppliers, business support services, labor force, ...) with high quality and low cost. Moreover, it also helps reduce shipping and transaction costs. Enterprises in the cluster could easily buy back related information as well as research and development process and technology. The development of industry linking clusters in South Korea has affected the following socio-economic issues: Firstly, strongly impact on the success for businesses in industry linking clusters; Secondly, improve the shortage of jobs in localities; Thirdly, strengthening national competitiveness; Fourthly, promote the development of a national balance.

In Japan, one of the main directions of the Japanese government in the implementation of the industry linking cluster development program is the policies

Table 1. Industrial policies and large industrial clusters in South Korea (Bong-Kyu, 2010).

\begin{tabular}{cccc}
\hline Year & 1960s & 1970s & 1980s \\
\hline Industrial policy & Light industry & $\begin{array}{c}\text { Heavy industry and } \\
\text { chemical industry }\end{array}$ & $\begin{array}{c}\text { Industry intensive } \\
\text { technology }\end{array}$ \\
Core enterprise (Area) & Textile & $\begin{array}{c}\text { Steel, machines, electronic, } \\
\text { petrochemical }\end{array}$ & Parts and materials \\
Information technology, \\
semiconductor,
\end{tabular}


that focusing on regional development. The process of creating the interaction system among the private sectors, research, and government agencies have not been fully developed yet. The program of developing industry linking clusters still faces some institutional barriers, such as the lack of a legal framework. In 2013, Japan through the science, technology and innovation development strategy, with a long-term vision on an ideal economic society. The government has developed a number of programs to support innovation development activities. Japan is known to be a country of widespread support of venture companies with a number of joint venture assistance programs in Japan, always providing timely and necessary support for new businesses. Objective of the industry linking cluster planning will continually create innovative activities with a long process of effort of the whole economy and policies with a vision for long-term and decades-long implementation. The priorities for industry linking clusters are leading industries, synchronized and focused policies. The initiatives of local agencies are also highly appreciated in the process of designing, planning and implementing industry linking cluster policies. There are guidance on the use of solutions and policies that is designed to support partnerships between enterprises and schools, among different enterprises, startups, related ministries and departments. Moreover, the policy instruments of government are closely implemented by local agencies. All participants are responsible for industry linking cluster activities to play a leading role in applying consistent solutions and policies with the vision for industry linking cluster. Local agencies are also proactive in building their own independent local organizations in the coordination to form industry linking cluster.

\section{Discussion for Developing Industry Linking Clusters in Vietnam}

Currently, the industry linking clusters have been existed and developed in Vietnam as following:

The traditional trade villages: There are 40,000 production facilities in nearly 3000 trade villages of which over $80 \%$ are individual households. These households are mainly producing similar or related products. These usually are in residential areas and enterprise owners are the villagers. These craft villages are playing an important role in the economic development of each locality. The craft villages also create jobs for about 20 million workers. Typical trade villages such as La Phu weaving, Dong Ky wood, Dai Bai copper, Da Hoi steel rolling... (Sơn, 2014). The present industry linking clusters are electronics industry cluster in the Hanoi region, the automobile and motorbike assembly industry group in the northern key economic region, the textile and garment industry cluster in the red river delta, a high-tech cluster, especially electronics and information technology in Ho Chi Minh city and neighboring provinces. Some other industry linking clusters can be listed as agricultural clusters in the Mekong delta, tourist cluster in Hue-Quang Nam-Da Nang provinces; coffee processing industry clus- 
ter in the central highlands, ...

Through the experience of developing industry linking clusters of many countries that have achieved certain achievements, Vietnam could summarize some experiences for the development of industry linking cluster in the context of international economic integration, such as:

Firstly, in order to develop industry linking cluster, it is necessary to have guiding documents of government in the context of international integration, the efforts of the enterprise community.

Secondly, Vietnam's planning work is still widespread, without any focus, the contents of the planning have not been closely linked, not ensuring the requirements of the development logic. Therefore, it is necessary to conduct research to apply the approach of developing industry linking clusters to the overall planning of socio-economic development. It will be the renewal of planning in general and the industry linking clusters in particular. The industry linking clusters will soon be formed and developed in our country.

Thirdly, there should be agreement on the views, perceptions and actions of the provinces, branches and localities throughout the country on developing industry linking clusters. The policies of developing industry linking clusters should be flexibly and practically applied on the basis of grasping the specific conditions of each locality.

Fourthly, depending on the specific models and conditions, the central government and local authorities could play different roles through the development of industry linking clusters. Therefore, the choice of the model of developing industry linking clusters should be carefully considered and flexibly applied based on the model characteristics as well as specific conditions of each locality.

\section{Conclusion}

The development of industry linking clusters in many countries like China, South Korea and Japan has studied and suggested that it play an important role in the nation's socio-economic development. The industry linking clusters have been discussed to develop them in Vietnam. In order to develop industry linking clusters in Vietnam, the present solutions have been presented. These solutions could be suggestions for the policy makers in Vietnam and the same condition countries.

\section{Conflicts of Interest}

The author declares no conflicts of interest regarding the publication of this paper.

\section{References}

Bong-Kyu, P. (2010). The Industrial Complex Cluster Program of Korea.

Hạnh, P. M. (2014). Mô hình phát triển cụm liên kết ngành tại một số khu vực của Trung Quốc. Tạp chí Nghiên cúu Trung Quốc, 11, 11-21. (in Vietnamese)

Kuchiki, A., \& Tsuji, M. (2008).The Flowchart Approach to Industrial Cluster Policy. New 
York: Palgrave Macmillan. https://doi.org/10.1057/9780230589520

Marshall, A. (1920). Principle of Economics. London: Macmillan.

Porter, M. (1990). The Competition Advantage of Nations. New York: The Free Press. https://doi.org/10.1007/978-1-349-11336-1

Rosenfeld, S. (1997). Bringing Business Clusters into the Mainstream of Economic Development. European Planning Studies, 5, 3-23. https://doi.org/10.1080/09654319708720381

Sơn, N. N. (2014). Phát triển cụm ngành công nghiệp ở Việt Nam trong điều kiện toàn cầu hóa và hội nhập quốc tế. Hanoi: National Political Publishing House. (in Vietnamese)

Sonobe, T., \& Otsuka, K. (2006). Cluster-Based Industrial Development: An East Asia Model. New York: Palgrave MacMillan. https://doi.org/10.1057/9780230596061 